\title{
Anti-inflammatory effect of vitamin D3 on chronic gingivitis
}

\section{Asmaa Y Thanoon BDS}

Faehaa Azher Al-Mashhadane BDS, MSc, PhD (Assist Prof.)

\author{
Department of Dental Basic Sciences \\ College of Dentistry, University of Mosul
}

Department of Dental Basic Sciences College of Dentistry, University of Mosul

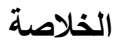

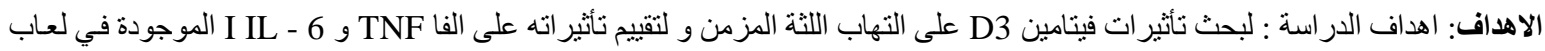

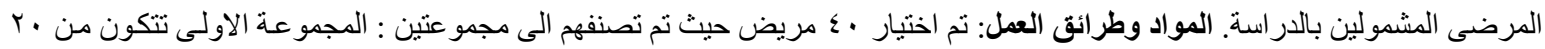

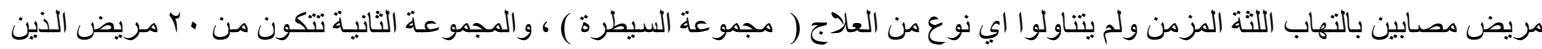

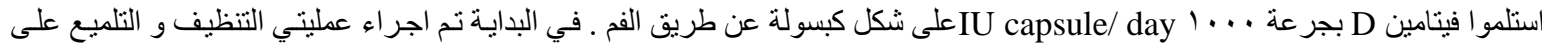

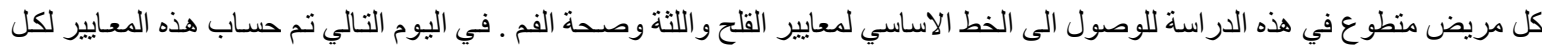

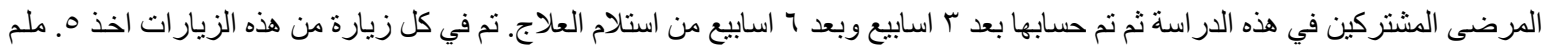

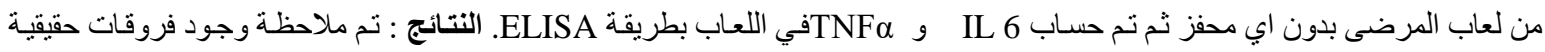

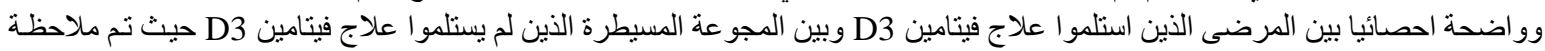

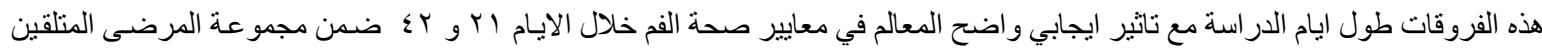

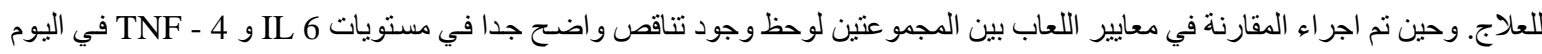

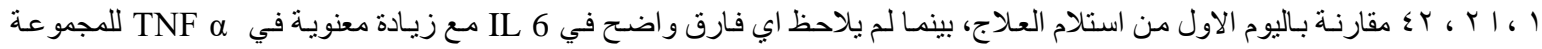

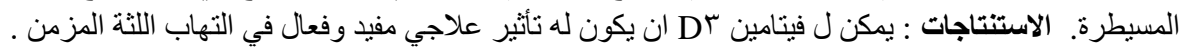

\begin{abstract}
Aims: To investigate the effects of vitamin D3 on chronic gingivitis and to evaluate its effect on Tumor necrosis factor- $\alpha$ and Interleukin- 6 in their saliva. Material and Method: Forty patients were classified into two groups: - group 1: (20) chronic gingivitis patients, did not receive any medication (control group), group 2: (20) chronic gingivitis patients (treatment group), received Vitamin D3 1000IU capsule/ day. Scaling and polishing have been carried out for each volunteer to reach the base line for gingival index, oral hygiene index and calculus index. Then these indices were measured for all patients on the next day, after 3 weeks and after 6 weeks in both groups. Five milliliters of unstimulated saliva were collected for measurement of human salivary Tumor necrosis factor- $\alpha$ and Interleukin- 6 by ELISA Kits. Results: significant differences were observed between treatment and control groups throughout study days with significant reduction in oral health indices in 21st and 42nd days of treatment group. Comparisons between the salivary parameters showed significant decreases in Tumor necrosis factor- $\alpha$ and Interleukin-6 levels throughout 1st, 21 st and 42nd day in treatment group, while in control group no significant differences were observed for IL-6 but significant increase in levels of TNF $\alpha$ was detected. Conclusion: Vitamin D3 has beneficial effect during treatment of chronic gingivitis.
\end{abstract}

Key words: Vitamin D3, Chronic gingivitis, TNF $\alpha$ and IL-6.

Thanoon AY., Al-Mashhadane FA. Anti-inflammatory effect of vitamin D3 on chronic gingivitis. AlRafidain Dent J. 2020 ;20 (1): 73-82.

DOI: $10.33899 /$ rden.2020.164541

Received: 11/3/2020 Sent to Referees: 15/3/2020 Accepted for Publication: 26/4/2020 


\section{INTRODUCTION}

Gingival diseases are frequent public health problem where vitamins supposed to have a role in the spread and cure of these diseases and thus promote oral and dental health ${ }^{1}$. Gingivitis is an inflammation of the gingiva. The cardinal signs of inflammation involving redness, swelling, bleeding, and exudation and to a lesser extent pain which gives an indication for the presence of gingivitis ${ }^{2}$. In recent, vitamin D research indicated that it can have useful effects on several body systems and it is essential for good and normal body functions. Vitamins (Vit) are organic substances available in small amounts in food stuffs. Usually people obtain vitamins from their feeding which is regarded as main supply, or as supplements ${ }^{3}$. Vitamins are of two categories, water soluble Vit (Vit B12, Vit C, folic acid, niacin Vit B3, Vit B1 and Vit B2) and fat soluble Vit (Vit K, Vit E, Vit D and Vit A) $)^{4}$. Vitamin D is formed in the skin when exposed to sunlight ${ }^{5}$.Vitamin D is one of the key regulators of inflammation and oxidative stress ${ }^{6}$. Cytokines proteins that play a vital multi-functional role in cell to cell communication such as IL-6 and TNF- $\alpha$ which adjust a number of physiological and pathological conditions, like inflammation, development, and cell apoptosis ${ }^{7}$. The release of these cytokines results in the enhancement of the inflammatory response ${ }^{8}$. These inflammatory cytokines are diagnosed by biological fluid such as blood, urine and oral fluids ${ }^{9}$. Saliva as oral fluid provides benefits over serum as its collection is non-invasive, and it is not costly for the broadcast of large numbers population ${ }^{10}$. This study aims to investigate the effects of vitamin D3 on plaque, gingival, oral health and calculus indices of patients with chronic gingivitis and to evaluate its effect on TNF- $\alpha$ and IL-6 in their saliva.

\section{MATERIALS AND METHODS}

This study was agreed by the scientific committee/department of Dental Basic Science/College, of Dentistry/University of Mosul. The samples were obtained from forty patients, their ages ranged between (20-40), recruited from the private dental clinics in Dohuk city. They were classified into two groups: - Group 1 included 20 chronic gingivitis patients (males and females) did not receive any medication (control group), Group 2 included 20 chronic gingivitis patients' males and females (treatment group), received Vitamin D3 1000 IU fast acting liquid soft gel (USA). The choice of each volunteer depended on inclusion criteria ( individuals without any systemic diseases , Non-pregnant or lactating females, no any drug or supplements, complement of more than 20 teeth, nonsmoking, non-alcoholic).Scaling and polishing had been carried out for each volunteer to reach the base line for plaque index(Silness and Loe, 1964), gingival index(Loe and Silness, 1963), oral hygiene index and calculus index(Greene and Vermilion, 1960). In the next day, these indices were measured for all participants and 
measured again 3 weeks and 6 weeks after treatment. At the same visits, five milliliters of unstimulated saliva were collected for measurement of TNF $\alpha$ Human ELISA Kit (MyBioSource,/USA ) and IL-6 by Salivary Interleukin-6 ELISA Kit (Salimetric @,USA). Statistical Analysis was carried by Microsoft Excel-2010. Independent t-test and One-way Analysis of Variance test (ANOVA-test) with Tukey's Pair-wise comparisons were used.

\section{RESULTS}

In this study significant differences were observed between treatment and control groups throughout study days, there were significant reduction in oral health indices in $\mathbf{2 1}^{\text {st }}$ and $\mathbf{4 2}^{\text {nd }}$ days of the study, which means good response to treatment and improvement in gingival health (Tables 1, 2 and 3).

Table (1): Comparison of oral health scores between the treatment and control groups at the beginning of study.

\begin{tabular}{lllc}
\hline Oral health scores & $\begin{array}{l}\text { Treatment group } \\
{[\mathbf{n}=\mathbf{2 0}]} \\
\text { Mean } \pm \text { SD }\end{array}$ & $\begin{array}{l}\text { Control group } \\
{[\mathbf{n = 2 0 ]}} \\
\text { Mean } \pm \text { SD }\end{array}$ & P-value* \\
\hline Gingival index & $0.784 \pm 0.519$ & $0.170 \pm 0.268$ & 0.000 \\
Oral hygiene index & $1.361 \pm 0.733$ & $0.606 \pm 0.589$ & 0.001 \\
Calculus index & $0.536 \pm 0.355$ & $0.290 \pm 0.277$ & 0.019 \\
\hline
\end{tabular}

* Independent T-test of two means was used, $\mathrm{p} \leq 0.05$ significant

Table (2): Comparison of oral health scores between the treatment and control groups at $21^{\text {st }}$ day of study.

\begin{tabular}{lllc}
\hline Oral health scores & $\begin{array}{l}\text { Treatment group } \\
{[\mathbf{n}=\mathbf{2 0}]} \\
\text { Mean } \pm \text { SD }\end{array}$ & $\begin{array}{l}\text { Control group } \\
{[\mathbf{n = 2 0 ]}} \\
\text { Mean } \pm \text { SD }\end{array}$ & P-value* \\
\hline Gingival index & $0.288 \pm 0.184$ & $0.481 \pm 0.295$ & 0.018 \\
Oral hygiene index & $0.457 \pm 0.315$ & $1.095 \pm 0.679$ & 0.000 \\
Calculus index & $0.253 \pm 0.138$ & $0.476 \pm 0.332$ & 0.009 \\
\hline
\end{tabular}

* Independent T-test of two means was used, $\mathrm{p} \leq 0.05$ significant 
Table (3): Comparison of oral health scores between the treatment and control groups at $42^{\text {nd }}$ day of study.

\begin{tabular}{llll}
\hline Oral health scores & $\begin{array}{l}\text { Treatment group } \\
{[\mathbf{n}=\mathbf{2 0}]} \\
\text { Mean } \pm \text { SD }\end{array}$ & $\begin{array}{l}\text { Control group } \\
{[\mathbf{n}=\mathbf{2 0}]} \\
\text { Mean } \pm \text { SD }\end{array}$ & P-value* \\
\hline Gingival index & $0.093 \pm 0.115$ & $0.738 \pm 0.344$ & 0.000 \\
Oral hygiene index & $0.185 \pm 0.202$ & $1.324 \pm 0.564$ & 0.000 \\
Calculus index & $0.099 \pm 0.090$ & $0.607 \pm 0.262$ & 0.000 \\
\hline
\end{tabular}

* Independent T-test of two means was used, $\mathrm{p} \leq 0.05$ significant

The differences in the oral health these indices after treatment period. There indices at the beginning of study might be were significant differences in all oral because of individual variations which health scores during the study days for both could be ignored because of the very treatment and control groups as shown in clearly significant effect of vitamin D on Tables 4 and 5

Table (4): Effect of systemic vitamin D treatment on oral health scores during study period.

\section{Treatment group}

\begin{tabular}{|c|c|c|c|c|}
\hline Oral health scores & $\begin{array}{l}1^{\text {st }} \text { day } \\
\text { Mean } \pm \text { SD }\end{array}$ & $\begin{array}{l}21^{\text {st }} \text { day } \\
\text { Mean } \pm \text { SD }\end{array}$ & $\begin{array}{l}42^{\text {nd }} \text { day } \\
\text { Mean } \pm \text { SD }\end{array}$ & P-value* \\
\hline Gingival index & $0.784 \pm 0.519^{\mathrm{A}}$ & $0.288 \pm 0.184^{\mathrm{B}}$ & $0.093 \pm 0.115^{\mathrm{B}}$ & 0.000 \\
\hline Oral hygiene index & $1.361 \pm 0.733^{\mathrm{A}}$ & $0.457 \pm 0.315^{\text {в }}$ & $0.185 \pm 0.202^{\text {В }}$ & 0.000 \\
\hline Calculus index & $0.536 \pm 0.355^{\mathrm{A}}$ & $0.253 \pm 0.138^{\text {В }}$ & $0.099 \pm 0.090^{\text {B }}$ & 0.000 \\
\hline
\end{tabular}

Table (5): Comparison of oral health scores of control group during the study period.

\section{Control group}

\begin{tabular}{lllll} 
Oral health scores & $\begin{array}{l}\mathbf{1}^{\text {st }} \text { day } \\
\text { Mean } \pm \text { SD }\end{array}$ & $\begin{array}{l}\mathbf{2 1}^{\text {st }} \text { day } \\
\text { Mean } \pm \text { SD }\end{array}$ & $\begin{array}{l}\mathbf{4 2}^{\text {nd }} \text { day } \\
\text { Mean } \pm \text { SD }\end{array}$ & P-value* \\
\hline Gingival index & $0.170 \pm 0.268^{\text {C }}$ & $0.481 \pm 0.295^{\mathrm{B}}$ & $0.738 \pm 0.344^{\mathrm{A}}$ & 0.000 \\
Oral hygiene index & $0.606 \pm 0.589^{\mathrm{B}}$ & $1.095 \pm 0.679^{\mathrm{A}}$ & $1.324 \pm 0.564^{\mathrm{A}}$ & 0.002 \\
Calculus index & $0.290 \pm 0.277^{\mathrm{B}}$ & $0.476 \pm 0.332^{\mathrm{AB}}$ & $0.607 \pm 0.262^{\mathrm{A}}$ & 0.004 \\
\hline
\end{tabular}

* One-way ANOVA-test with Tukey's Pair wise comparisons was used. Mean values with the same letters were statistically non- significant $(\mathrm{p}>0.05)$ 
Also in this study a significant difference factor at the beginning of the study, the $21^{\text {st }}$ day was found between means of treatment group and on the $42^{\text {nd }}$ day of the study as illustrated in and control group in salivary IL-6 and TNF $\alpha$ (Tables 6,7 and 8 ).

Table (6): Comparison in salivary levels of IL-6 and TNF- $\alpha$ between the treatment and control groups at the beginning of the study.

\begin{tabular}{llll}
\hline Salivary parameters & $\begin{array}{l}\text { Treatment group } \\
{[\mathbf{n}=\mathbf{2 0}]} \\
\text { Mean } \pm \text { SD }\end{array}$ & $\begin{array}{l}\text { Control group } \\
{[\mathbf{n}=\mathbf{2 0}]} \\
\text { Mean } \pm \text { SD }\end{array}$ & P-value* \\
\hline Interlukine-6 $(\mathrm{Pg} / \mathrm{ml})$ & $2.40 \pm 0.25$ & $2.80 \pm 0.65$ & 0.014 \\
TNF- $\alpha(\mathrm{Pg} / \mathrm{ml})$ & $30.89 \pm 8.85$ & $16.73 \pm 1.15$ & 0.000 \\
\hline
\end{tabular}

* Independent $\mathrm{T}$-test of two means was used. $\mathrm{p} \leq 0.05$ significant.

Table (7): Comparison in salivary levels of IL- 6 and TNF- $\alpha$ between the treatment and control groups at $21^{\text {st }}$ day of the study.

\begin{tabular}{cccc}
\hline Salivary parameters & $\begin{array}{c}\text { Treatment group } \\
{[\mathbf{n}=\mathbf{2 0}]} \\
\text { Mean } \pm \text { SD }\end{array}$ & $\begin{array}{c}\text { Control group } \\
{[\mathbf{n}=\mathbf{2 0}]} \\
\text { Mean } \pm \text { SD }\end{array}$ & P-value* \\
\hline Interlukine-6 $(\mathrm{Pg} / \mathrm{ml})$ & $1.54 \pm 0.413$ & $2.72 \pm 0.54$ & 0.000 \\
TNF- $\alpha(\mathrm{Pg} / \mathrm{ml})$ & $26.90 \pm 7.64$ & $17.47 \pm 1.75$ & 0.000 \\
\hline
\end{tabular}

* Independent T-test of two means was used. $\mathrm{p} \leq 0.05$ significant.

Table (8): Comparison in salivary levels of IL-6 and TNF- $\alpha$ between the treatment and control groups at $42^{\text {nd }}$ day of the study.

\begin{tabular}{llll}
\hline Salivary parameters & $\begin{array}{l}\text { Treatment group } \\
{[\mathbf{n}=\mathbf{2 0}]} \\
\text { Mean } \pm \text { SD }\end{array}$ & $\begin{array}{l}\text { Control group } \\
{[\mathbf{n = 2 0 ]}} \\
\text { Mean } \pm \text { SD }\end{array}$ & P-value* \\
\hline Interlukine-6 $(\mathrm{Pg} / \mathrm{ml})$ & $1.07 \pm 0.27$ & $2.94 \pm 0.83$ & 0.000 \\
TNF- $\alpha(\mathrm{Pg} / \mathrm{ml})$ & $20.39 \pm 6.40$ & $27.17 \pm 13.16$ & 0.045 \\
\hline
\end{tabular}

* Independent T-test of two means was used. $\mathrm{p} \leq 0.05$ significant.

Comparisons of salivary parameters levels $42^{\text {nd }}$ day of the study as illustrated in (Table 9 as a result of effect of Vitamin D3 treatment ), while in the control group during the study during the study period showed a significant period we observed no significant difference in difference in the means of the salivary IL-6 IL-6 but a significant difference in salivary and Salivary TNF $\alpha$ level during $1^{\text {st }}, 21^{\text {st }}$ and TNF $\alpha$ as illustrated in (Table 10) 
Table (9): Effect of systemic vitamin D treatment on salivary levels of IL-6 and TNF- $\alpha$ during the study period.

Treatment group

\begin{tabular}{lllll} 
Salivary parameters & $\begin{array}{l}\mathbf{1}^{\text {st }} \text { day } \\
\text { Mean } \pm \text { SD }\end{array}$ & $\begin{array}{l}\mathbf{2 1}^{\text {st }} \text { day } \\
\text { Mean } \pm \text { SD }\end{array}$ & $\begin{array}{l}\mathbf{4 2}^{\text {nd }} \text { day } \\
\text { Mean } \pm \text { SD }\end{array}$ & P-value* \\
\hline Interlukine-6 $(\mathrm{Pg} / \mathrm{ml})$ & $2.40 \pm 0.25^{\mathrm{A}}$ & $1.54 \pm 0.413^{\mathrm{B}}$ & $1.07 \pm 0.27^{\mathrm{C}}$ & 0.000 \\
TNF- $\alpha(\mathrm{Pg} / \mathrm{ml})$ & $30.89 \pm 8.85^{\mathrm{A}}$ & $26.90 \pm 7.64^{\mathrm{A}}$ & $20.39 \pm 6.40^{\mathrm{B}}$ & 0.000
\end{tabular}

* One-way ANOVA-test with Tukey's Pair wise comparisons was used. Means with the same letters were statistically non significant $(\mathrm{p}>0.05)$

Table (10): Comparison in salivary levels of IL-6 and TNF- $\alpha$ of control group during the study period.

\begin{tabular}{|c|c|c|c|c|}
\hline & Control group & & & \\
\hline Salivary parameters & $\begin{array}{l}1^{\text {st }} \text { day } \\
\text { Mean } \pm \text { SD }\end{array}$ & $\begin{array}{l}21^{\text {st }} \text { day } \\
\text { Mean } \pm \text { SD }\end{array}$ & $\begin{array}{l}42^{\text {nd }} \text { day } \\
\text { Mean } \pm \text { SD }\end{array}$ & P-value* \\
\hline Interlukine-6 (Pg/ml) & $2.80 \pm 0.65^{\mathrm{A}}$ & $2.72 \pm 0.54^{\mathrm{A}}$ & $2.94 \pm 0.83^{\mathrm{A}}$ & 0.590 \\
\hline TNF- $\alpha(\mathrm{Pg} / \mathrm{ml})$ & $16.73 \pm 1.15^{\mathrm{B}}$ & $17.47 \pm 1.75^{\mathrm{B}}$ & $27.17 \pm 13.16^{\mathrm{A}}$ & 0.000 \\
\hline
\end{tabular}

* One-way ANOVA-test with Tukey's Pair wise comparisons was used. Means with the same letters were statistically non significant $(\mathrm{p}>0.05)$

\section{DISCUSSION}

Gum tissue inflammation "Gingivitis" is disease of a large variety of etiological local causes such as dental plaque, food impaction, irritating restoration. In addition to several systemic factors such as pregnancy, diabetes, nutritional alterations and other ${ }^{11}$. Plaque is the most frequent cause of gingivitis result from bacteria at marginal gingiva ${ }^{12}$. The connection between plaque and gingival inflammation has habitually postulated as the source of this inflammation and it has long-established role in experimental studies $^{13}$. Cytokines, a multifarious network, have a role in the immune response of the body against attacks and cooperate communications between inflammatory cells after the activation of the immunity ${ }^{14}$. Gingival bacteria trigger the innate immunological response causing inflammation of the gum tissue, an abundant sequence of macrophages that in turn produce interleukin. At persistent inflammation of the gingiva, it is assumed that the interleukins will be changed and adjusted in patients with this kind of pathology ${ }^{15}$. Results of this study demonstrated high levels of in salivary IL- 6 and TNF $\alpha$ factor at the beginning of the study which agree with the fact that IL- 6 and TNF $\alpha$ play a role in the pathogenesis of gingival inflammation ${ }^{16}$. These changes in the level of inflammatory mediators be a sign of an inflammation and may influence the further dynamics of the inflammatory 
course in the periodontal tissues ${ }^{17}$. Vitamin D as a regulator during the immune reaction, stimulating immune response at sometimes, while inhibiting it at others ${ }^{18}{ }^{19}$. A study established that an increased construction of the antibacterial protein's "beta-defensins and cathelicidin" will ocuures after exposure to antigens, and that Vitamin D enhanced such bactericidal activity of these proteins ${ }^{20}$. In the present study, effect of Vitamin D3 during the study period showed significant decline in the means of the salivary IL-6 and Salivary TNF $\alpha$ level at base line and subsequent visits of the study while in the control group no significant difference in IL-6 level with significant increases in salivary TNF $\alpha$ during the study period. Vitamin D also improves the capacity of gingival epithelial cell to act against the attack of pathogens and slow down the inflammatory response. Gingival epithelial cell can switch inactive vitamin $\mathrm{D}$ to the active form in situ, supporting the theory that it can be introduced to the gingiva directly to avoid periodontal diseases or treat them ${ }^{21,22}$. For the previously mentioned causes, vitamin D3 supplementation could has an effect on treatment of gingivitis ${ }^{23}$.This also could explains the condition of patients with chronic gingivitis associated with dietary restriction of vitamin D3.They have greater increase the severity of inflammation of the gingival diagnosed clinically by oral health scores and biochemically by salivary parameters ${ }^{24,25}$. Update confirmations about the anti- inflammatory effects of vitamin D3 for the treatment of patients with chronic gingivitis will be supported by the results of this study ${ }^{26}$. So, it is valuable to include Vitamin D3 supplement in treatment of gingivitis ${ }^{27}$.

\section{CONCLUSION}

Vitamin D3 supplements could be useful in treatment of gingivitis and could provide beneficial approach in periodontal therapy.

\section{Acknowledgment}

Authors are greatly appreciative to the University of Mosul / College of Dentistry for their kind assessment to reach best quality of this research.

\section{REFERENCES}

1. Christakos S, Dhawan P, Verstuyf A, Verlinden L, Carmeliet G. Vitamin D: metabolism, molecular mechanism of action, and pleiotropic effects. Physiol Rev. 2016; 96(1):365-408. doi10.1152/physrev.00014.2015.

2. Bringhurst FR., Demay M. B., Krane S. M., Kronenberg H. M. Bone and mineral metabolism in health and disease. In: Kasper D. L., Fauci A. S., Hauser S. L., Longo D. L., Jameson L. J., Loscalzo J., editors. Harrison's principles of internal medicine. Vol. 2. McGraw Hill; 2015. pp. 2454-2465.

3. Hassan BAR. Vitamins (Importance and Toxicity). Pharmaceut Anal Acta. 
2012; 3: e125. doi:10.4172/2153$2435.1000 \mathrm{e} 125$.

4. Wolf G. The discovery of Vitamin D: the contribution pf Adolf Windaus. J Nutr. 2004; 134: 1299 - 302.

5. World Health Organization and Food and Agriculture Organization of the United Nations. Vitamin and mineral requirements in human nutrition. Second edition.2004:341..

6. Kochwvar IE, Taylor CR, Krutmann J. Fundamentals of cutaneous photobiology and photoimmunology. In: Wolff K., Goldsmith L. A., Katz S. I., et al., editors. in Fitzpatrick's Dermatology in General Medicine. Vol. 2. New York, NY, USA: McGraw-Hill; 2012: 1031-1048.

7. Baud V, Karin M. Signal transduction by tumor necrosis factor and its relatives, Trends Cell Biol. 2001; 11:372-377.

8. Hossein-Nezhad A., Holick M. F. Vitamin D for health: a global perspective. Mayo Clinic Proceedings. 2013;88(7):720-755. doi: 10.1016/j.mayocp.2013.05.011.

9. Sunil J, Awansa W,Orc ID. Vitamin D Deficiency: Effects on Oxidative Stress, Epigenetics, Gene Regulation, and Aging. Biology. 2019, 8(2): 30.

10. Piler P, Kandrnal V, Lubomír Kukla L, Andrýsková L, Švancara J, Jarkovský J, Cohort Profile: The
European Longitudinal Study of Pregnancy and Childhood (ELSPAC) in the Czech Republic Int J Epidemiol. 2017 Oct; 46(5): 1379-1379f. doi: 10.1093/ije/dyw091

11. Armitage GC. Classifying periodontal diseases - a long-standing dilemma. Periodontol 2000. 2002; 30:9-23.

12. Bogren A, Teles R, Torresyap G, Haffajee AD, Socransky SS, Lindhe J. A three-year prospective study of adult subjects with gingivitis. I: Clinical periodontal parameters. J ClinPeriodontol. 2007; 34:1-6.

13. Löe H, Theilade E, Börglum S. Experimental gingivitis in man. $\mathrm{J}$ Period. 1965; 36:177-87.

14. Yücel O, Berker E, Gariboglu S, Otlu H. Interleukin-11, interleukin-1 $\beta$, interleukin-12 and the pathogenesis of inflammatory periodontal diseases. J Clin Periodontol. 2008; 35:365-70.

15. Montserrat Boronat- Catala , Montserrat Catala-pizzaro, Jose V. Bagan Sebastian . Salivary and crevicular fluid interleukins in gingivitis. J Clin Exp Dent. 2014;6(2): e175-9. doi:10.4317/jced.51403

16. Holla LI, Musilova K, Löe $\mathrm{H}$, Theilade E, Börglum S. Experimental gingivitis in man. J Period. 1965; 36:177-87.

17. Vokurka J, Klapusova J, Pantuckova P, kukletova M, Holla L. musilova K. 
Association of interleukin-6 (IL-6) haplotypes with plaque- induced gingivitis in children. Acta Odontologica Scandinavica, 2008; 66: 105-112

DOI: 10.1080/00016350802004664.

18. Berezniakova Al, Cheremisina VF. 4 and 6 interleukin's action in the pathogenesis of periodontitis, gingivitis and dental alveolitis. wiad Lek: 2017;70(5):910-912

19. Jiang C, Huang Y. Coronarin D affects TNF $\alpha$ induced proliferation and osteogenic differentiation of human periodontal ligament stem cells. Archives of Oral Biology,2019, 108:104519.DOI: 10.1016/j.archoralbio .2019 .104519 .

20. Bhargava A, Rastogi P, Lal N, Singhal R, Khatoon S, and Mahdi AA. Relationship between VITAMIN $\mathrm{D}$ and chronic periodontitis. Journal of Oral Biology and Craniofacial Research, 2019, 9( 2): 177-179. DOI: 10.1016/j.jobcr.2018.07.001.

21. Bonnet C, Rabbani R, Moffatt M, Kelekis- Cholakis A, Schroth RJ. The Relation Between Periodontal Disease and Vitamin D. J Can Dent Assoc, 2019. 2019;85: j4.

22. Menzel LP, Ruddick W, Chowdhury MH, Brice DC, $\underline{\text { Clance }}$ R, Porcelli E, et al. Activation of Vitamin D in the Gingival Epithelium and Its Role in
Gingival Inflammation and Alveolar Bone Loss. J Periodontal Res. 2019. 54 (4): 444-452. DOI: $\underline{10.1111 / j r e .12646}$

23. GaO W, Tang H, Wang D, Zhou X, Song Y, Wang Z. effect of short-term Vitamin D supplementation after nonsurgical periodontal treatment: A randomized, double masked, placebocontrolled clinical trial. J Periodont Res. 2020; 00:1-9.

DOI: $10.1111 /$ jre. 12719

PMID: 31960448.

24. Menzel LP, Ruddick W , Chowdhury MH. Activation of Vitamin D in the gingival epithelium and its role in gingival inflammation and alveolar bone loss. J Periodont Res. 2019;1-9. https://doi.org/10.1111/jre.12646.

25. Syndergaard B, Al-Sabbagh M, Kryscio RJ, Ding JX, Ebersole JL and Miller CS. Salivary Biomarkers Associated with Gingivitis and Response to Therapy. published online; J Periodontol. 2014, 85(8): e295-e303. 6,DOI: 10.1902/jop.2014.130696,

26. Feng Y, Yang DS, Tang HB, Ding YS, Li XG. Effectiveness of vitamin D for adult patients with gingivitis. Medicine 2020;99:2

(e18338).doi: 10.1097/MD.000000000 0018338.

27. Khammissa RG, Ballyram R, Jadwat Y, Fourie J, Lemmer J, Feller L. Vitamin D Deficiency as It Relates 
to Oral Immunity and Chronic Periodontitis. International Journal of
Dentistry.2018, Article ID 7315797:9. DOI: 10.1155/2018/7315797. 